Al-Bayyinah: Journal of Islamic Law-ISSN: 1979-7486 (p);

2580-5088 (e) Volume VI Number 2, pp. 99-113

\title{
ALTERNATIF DALAM PENYELESAIAN SENGKETA (LITIGASI DAN NON LITIGASI)
}

\section{Rosita}

(Dosen Tetap STAIN Watampone, Sulawesi Selatan, Indonesia, email: rosita.iainbone@gmail.com)

\section{Abstract}

There are two ways to settle a dispute: a) litigation, the process of settling a dispute through court system. The dispute settlement by litigation will follow legal procedures in a court, b) non-litigation, dispute settlement out of court system, for example, through negotiation, mediation, arbitration, conciliation, and settlement mediated by kepala desa (village leader) based on local customary law. Each way has its own particular advantages. A settlement through litigation is final, binding, and forcing the litigants to obey the implementation of a verdict. Therefore, an execution is provided as a forcing institution. Meanwhile, a nonlitigation system settles disputes in a faster way, financially more efficient, and the verdict may variously be adapted to a broad agreement.

\section{Kata Kunci: Penyelesaian sengketa, litigasi, dan non litigasi}

\section{PENDAHULUAN}

Masyarakat merupakan kumpulan manusia yang hidup bersama untuk waktu yang relatif lama dan memiliki kesadaran bahwa mereka merupakan satu kesatuan yang terikat pada satu sistem kehidupan bersama, dimana di dalamnya terdapat berbagai kaidah yang bertujuan untuk mengatur bagaimana warganya bertingkah laku.

Dalam kehidupan masyarakat manapun terdapat berbagai bentuk kepentingan. Kepentingan tersebut ada yang 
selaras satu sama lain, tetapi ada juga yang saling bertentangan satu dengan yang lain. Apabila terdapat dua atau lebih kepentingan yang saling bertentangan, maka terjadilah bentrok kepentingan. Inilah yang dalam istilah yuridis dinamakan sengketa.

Sengketa ini adakalanya dapat diselesaikan secara damai, tetapi adakalanya konflik tersebut menimbulkan ketegangan yang terus menerus sehingga mengakibatkan kerugian pada kedua belah pihak. Agar dalam mempertahankan kepentingan masing-masing pihak itu tidak melampaui batasbatas dari norma yang ditentukan maka perbuatan main hakim sendiri (eigenrichting) haruslah dihindarkan. Apabila para pihak merasa ha-haknya dirugikan, maka ia dapat memutuskan untuk mencari cara-cara penyelesaian sengketa tersebut yang menurut mereka dapat menyelesaikan konflik yang terjadi.

Mengacu pada latar belakang pemikiran di atas, maka permasalahan pokok yang akan dibahas adalah: alternatif penyelesaian sengketa apa saja yang dapat digunakan oleh pihak-pihak yang berkepentingan dalam menyelesaikan sengketanya?

\section{PEMBAHASAN}

\section{A. Penyelesaian Sengketa Secara Litigasi}

Proses penyelesaian sengketa oleh para pihak yang bersengketa dapat dilakukan melalui jalur litigasi atau lembaga peradilan negara. Hal ini berarti sengketa tersebut akan diperiksa oleh hakim pengadilan dalam suatu rangkaian persidangan. Penyelenggaraan peradilan dilaksanakan oleh sebuah Mahkamah Agung dan badan peradilan yang berada di bawahnya dalam lingkungan Peradilan Umum, Peradilan Agama, Peradilan militer, peradilan tata usaha negara, dan oleh sebuah Mahkamah Konstitusi.

Pengadilan sebagai pelaksana kekuasaan kehakiman mempunyai tugas pokok untuk menerima, memeriksa, dan mengadili serta menyelesaikan setiap sengketa yang diajukan kepadanya guna menegakkan hukum dan keadilan berdasarkan

${ }^{1}$ Achmadi Ali, menguak Tabir Hukum (Suatu Kajian Filosofis dan Sosiologis), (Cet. I; Jakarta: Chandra Pratama, 1996), h. 320-321. 
Pancasila, demi terselenggaranya negara hukum Republik Indonesia.

Kelebihan penyelesaian sengketa secara litigasi adalah putusan pengadilan mempunyai kekuatan hukum yang pasti, bersifat final, menciptakan kepastian hukum dengan posisi para pihak menang atau kalah (win and lose position), dan dapat dipaksakan pelaksanaan putusannya apabila pihak yang kalah tidak mau melaksanakan isi putusan pengadilan (eksekusi). Oleh Sudikno Mertokusumo ${ }^{2}$ dikatakan bahwa putusan pengadilan mempunyai tiga macam kekuatan yang merupakan keistimewaan penyelesaian sengketa secara litigasi, yakni putusan pengadilan mempunyai kekuatan mengikat, kekuatan pembuktian, dan kekuatan eksekutorial atau kekuatan untuk dilaksanakan.

- Kekuatan mengikat

Putusan hakim mempunyai kekuatan mengikat, artinya putusan hakim itu mengikat para pihak yang berperkara dan yang terlibat dalam perkara itu. Para pihak harus tunduk dan menghormati putusan hakim tersebut. Putusan hakim yang telah memperoleh kekuatan hukum tetap tidak dapat diubah, sekalipun oleh pengadilan yang lebih tinggi kecuali dengan upaya hukum yang luar biasa (peninjauan kembali/request civil).

Terikatnya para pihak pada putusan hakim itu, baik dalam arti positif maupun negatif. Mengikat dalam arti positif, yakni apa yang telah diputus oleh hakim harus dianggap benar (res judicata pro veritate habetur). Mengikat dalam arti negatif, yakni hakim tidak boleh memutus lagi perkara yang pernah diputus sebelumnya antara pihak yang sama serta mengenai pokok perkara yang sama (nebis in idem).

- Kekuatan pembuktian

Putusan hakim mempunyai kekuatan pembuktian, artinya dengan putusan hakim itu telah diperoleh kepastian tentang sesuatu yang terkandung dalam putusan itu. Dituangkannya putusan hakim dalam bentuk tertulis yang merupakan akta otentik tidak lain bertujuan untuk dapat digunakan sebagai alat bukti bagi para pihak yang mungkin diperlukan untuk mengajukan banding, kasasi, peninjauan

${ }^{2}$ Sudikno Mertokusumo, Hukum Acara Perdata Indonesia (Cet. I; Yogyakarta: Liberty, 1993), h. 177-182. 
kembali atau upaya hukum lainnya, dan untuk pelaksanaan putusan.

- Kekuatan eksekutorial

Putusan hakim mempunyai kekuatan eksekutorial, artinya bahwa suatu putusan dimaksudkan untuk menyelesaikan suatu persoalan atau perkara dan menetapkan hak atau hukumnya saja, melainkan juga realisasi pelaksanaannya (eksekusinya) secara paksa. Kekuatan mengikat saja dari suatu putusan hakim belum cukup dan tidak akan berarti apabila putusan itu tidk dapat direalisasikan atau dilaksanakan.

Oleh karena putusan itu menetapkan dengan tegas hak dan hukumnya untuk kemudian direalisasikan, maka putusan hakim mempunyai kekuatan eksekutorial, yaitu kekuatan untuk dilaksanakan apa yang ditetapkan dalam putusan hakim itu secara paksa oleh alat-alat negara.

\section{B. Penyelesaian Sengketa Secara Non Litigasi}

Penyelesaian sengketa melalui jalur litigasi (pengadilan) bukanlah merupakan satu-satuya cara penyelesaian sengketa yang dapat ditempuh oleh para pihak yang bersengketa. Selain litigasi, terdapat penyelesaian sengketa di luar pengadilan (non litigasi), yaitu penyelesaian sengketa melalui negosiasi (musyawarah), mediasi, arbitrase, dan konsiliasi.

Selain itu terdapat pula bentuk penyelesaian sengketa yang sangat akrab diaktualisasikan dalam kehidupan masyarakat sehari-hari, yakni penyelesaian sengketa secara damai oleh kepala desa. Penyelesaian sengketa dengan cara ini pada dasarnya dapat diterima oleh para pihak yang bersengketa karena prosesnya didasarkan pada pengaturan sendiri dan masih kental diwarnai dengan adat kebiasaan setempat. Semua hal yang telah disepakati merupakan keputusan bersama para pihak yang bersengketa.

Metode penyelesaian sengketa melalui jalur non litigasi sebagaimana yang telah disebutkan sebelumnya dapat diuraikan sebagai berikut:

1. Penyelesaian sengketa melalui negosiasi

Untuk menyelesaikan suatu sengketa, salah satu cara yang dapat ditempuh adalah para pihak yang bersengketa 
melakukan negosiasi, yaitu cara untuk mencari penyelesaian masalah melalui musyawarah untuk mencapai kata sepakat secara langsung antara pihak-pihak yang bersengketa yang hasilnya dapat diterima oleh para pihak tersebut. ${ }^{3}$

Dalam praktik negosiasi dilakukan karena dua alasan, yakni:

a. Untuk mencari sesuatu yang baru yang tidak dapat dilakukannya sendiri, misalnya dalam transaksi jual beli, pihak penjual dan pembeli saling memerlukan untuk menentukan harga (di sini tidak terjadi sengketa).

b. Untuk memecahkan perselisihan atau sengketa yang timbul di antara para pihak. ${ }^{4}$

Dalam Pasal 6 ayat (1) UU Nomor 30 Tahun 1999 tentang Arbitrase dan Alternatif Penyelesaian Sengketa disebutkan bahwa sengketa atau beda pendapat perdata dapat diselesaikan oleh para pihak melalui alternatif penyelesaian sengketa yang didasarkan pada itikad baik dengan mengesampingkan penyelesaian secara litigasi di Pengadilan Negeri. ${ }^{5}$

Ketentuan peraturan perundang-undangan tersebut menunjukkan bahwa pada dasarnya para pihak yang bersengketa berhak untuk menyelesaikan sendiri sengketa yang timbul di antara mereka tanpa perlu beracara di pengadilan.

Munir Fuady membedakan penyelesaian sengketa melalui negosiasi atas dua jenis, yaitu:

a. Negosiasi Kepentingan

Negosiasi kepentingan (interest negotiation) merupakan negosiasi yang sebelum bernegoisasi sama sekali para pihak tidak ada hak-hak apapun dari satu pihak kepada pihak lain. Mereka bernegosiasi karena masingmasing pihak ada kepentingan untuk melakukan negosiasi

${ }^{3}$ Gatot Soemartono, Arbitrase dan Mediasi di Indonesia (Cet. I; Jakarta: PT Gramedia Pustaka Utama, 2006), h. 1.

${ }^{4} I b i d .$, h. 2.

${ }^{5}$ Republik Indonesia, "UU Noor 30 Tahun 1999 tentang Arbitrase dan Alternatif Penyelesaian Sengketa" dalam Gatot Soemartono, Arbitrase dan Mediasi di Indonesia (Cet. I; Jakarta: PT Gramedia Pustaka Utama, 2006), h. 164. 
tersebut. misalnya, negosiasi terhadap harga, penyerahan, waktu pembayaran, terms dan kondisi kontrak jual beli antara calon pembeli dengan calon penjual dalam hal pembelian benda tertentu. Apabila negosiasi kepentingan para pihak yang bernegosiasi tidak berhasil menemukan suatu kata sepakat, maka secara umum dapat dikatakan bahwa tidak satu pihak pun dapat memaksakan kehendak untuk tetap melanjutkan negosiasi.

b. Negosiasi Hak

Sebaliknya dalam negosiasi hak (right negotiation), sebelum para pihak bernegosiasi, di antara para pihak telah terlebih dahulu mempunyai hubungan hukum tertentu, sehingga antara para pihak telah menimbulkan hak-hak tertentu yang dijamin pemenuhannya oleh hukum. Kemudian para pihak bernegosiasi bagaimana agar hak-hak tersebut dapat dipenuhi oleh pihak lawan. Jadi berbeda dengan negosiasi kepentingan di mana negosiasi tersebut baru dimaksudkan untuk menciptakan hubungan hukum tertentu, sedangkan dalam negosiasi hak hubungan hukum justru telah ada sebelum negosiasi dilakukan. ${ }^{6}$

Berdasarkan Pasal 6 ayat (2) UU Nomor 30 Tahun 1999 tentang Arbitrase dan Alternatif Penyelesaian Sengketa dapat diketahui bahwa pada dasarnya para pihak dapat menyelesaikan sendiri sengketa yang timbul di antara mereka dalam suatu pertemuan langsung. Selanjutnya, kesepakatan mengenai penyelesaian tersebut dituangkan dalam bentuk ketentuan hukum tentang perdamaian yang terdapa dalam Pasal 1851 sampai dengan Pasal 1864 Buku III Kitab Undang-Undang Hukum Perdata.

Selanjutnya, Gunawan Wijaya dan Achmad Yani mengemukakan bahwa oleh karena kesepakatan tertulis hasil negosiasi adalah suatu persetujuan di antarapara pihak, maka selayaknya juga jika hasil negosiasi tidak dapat dibantah dengan alasan kekhilafan telah dirugikan. Walaupun demikian, masih terbuka kemungkinan untuk tetap dapat dibatalkan, jika memang dapat dibuktikan telah terjadi suatu kekhilafan mengenai orangnya, atau

${ }^{6}$ Munir Fuady, Arbitrase Nasional (Alternatif Penyelesaian Sengketa Bisnis), (Bandung: PT citra Aditya Bakti, 2004), h. 43. 
kesepakatan yang telah diadakan atas dasar surat-surat yang kemudian dinyatakan palsu. ${ }^{7}$

Negosiasi pada dasarnya ditempuh oleh para pihak yang bersengketa untuk menyelesaikan sengketanya dengan tujuan untuk mencapai kesepakatan bersama. Dalam hal ini Sudargo Gautama menyebutkan bahwa negosiasi merupakan proses untuk mencapai kesepakatan dengan pihak lain, yakni suatu proses interaksi dan komunikasi yang dinamis dan beraneka ragam, dapat lembut dan bernuansa sebagaimana manusia itu sendiri. ${ }^{8}$

Apabila para pihak dalam menyelesaikan sengketa secara negosiasi mengalami jalan buntu atau dengan kata lain tidak tercapai suatu kesepakatan atau persetujuan, maka para pihak yang bersengketa dapat menempuh cara lain untuk menyelesaikan sengketanya.

2. Penyelesaian sengketa melalui mediasi

Mediasi juga merupakan salah satu bentuk atau cara penyelesaian sengketa di luar pengadilan. Berbeda halnya dengan negosiasi, proses penyelesaian sengketa melalui mediasi dapat melibatkan orang lain atau pihak ketiga sebagai mediator.

Dasar hukum tentang mediasi dapat ditemukan dalam Pasal 6 ayat (3), (4), (5) UU Nomor 30 Tahun 1999 tentang Arbitrase dan Alternatif Penyelesaian Sengketa. Ketentuan hukum tentang mediasi yang diatur dalam UU Nomor 30 Tahun 1999 tersebut merupakan suatu proses kegiatan sebagai kelanjutan dari gagalnya negosiasi yang dilakukan oleh para pihak yang bersengketa.

Pasal 6 ayat (3) UU Nomor 30 Tahun 1999 mengemukakan bahwa dalam hal sengketa atau beda pendapat antara para pihak yang bersengketa tidak dapat diselesaikan, maka atas kesepakatan tertulis para pihak, sengketa atau beda pendapat diselesaikan melalui bantuan seorang atau lebih penasihat ahli maupun melalui seorang mediator. ${ }^{9}$

${ }^{7}$ Gunawan Wijaya dan Achmad Yani, hukum Arbitrase (Jakarta: PT Raja Grafindo Persada, 2000), h. 32.

${ }^{8}$ Ida Bagus Wyasa Putra, Aspek-aspek Hukum Perdata Internasional dalam Transaksi Bisnis Internasional (Cet. I; Bandung: Refika Aditama, 2000), h. 77.

${ }^{9}$ Republik Indonesia, “UU”, op. cit., h. 165. 
Achmad Ali mengemukakan bahwa mediator adalah seorang netral dan tidak bertindak sebagai seorang hakim, dia tidak mempunyai otoritas untuk menjatuhkan suatu putusan. Malahan mediator memimpin suatu pemeriksaan tatap muka dengan pihak yang bersengketa dan menggunakan keterampilan khusus tentang bagaimana mendengarkan problem para pihak, keterampilan bertanya, bernegosiasi dan membuat pilihan, membuat para pihak menentukan solusi mereka terhadap persengketaan mereka. ${ }^{10}$

Mediasi pada hakekatnya merupakan suatu bentuk penyelesaian sengketa yang memberikan pandangan ke depan terhadap para pihak yang bersengketa. Menurut Priyatna Abdurrasyid, mediasi sebagai suatu proses penyelesaian sengketa bekerja sangat baik. Mediasi memandang ke masa depan bukan ke masa lampau. Hukum memandang ke belakang untuk menentukan siapa yag benar dan siapa yang salah, sedangkan mediasi memandang ke depan untuk menemukan suatu solusi di mana para pihak dapat menyelesaikan sendiri sengketanya. Di dalam hukum, pengadilan mengemukakan kekuasaannya untuk memerintahkan suatu putusan, sedangkan di dalam mediasi keputusan diambil secara bersama-sama oleh para pihak. ${ }^{11}$

Berdasarkan berbagai pandangan di atas, maka dapat dipahami bahwa mediasi pada dasarnya merupakan cara dalam menyelesaikan sengketa oleh para pihak, di mana para pihak dapat menentukan atau menunjuk pihak ketiga untuk bertindak sebagai penengah atau mediator. Mediator tersebut dapat negara, organisasi, atau individu. Kedudukan mediator dalam hal ini adalah berusaha memberikan keseimbangan para pihak yang bersengketa sehingga mereka dapat dipertemukan dalam suatu keadaan yang sama-sama menguntungkan. Harus pula dipahami bahwa mediator dalam menangani sengketa para pihak, tidak berada pada posisi yang dapat memaksa salah satu pihak untuk menerima apa yang dikehendaki oleh pihak lainnya.

${ }^{10}$ Achmad Ali, Pengadilan dan Masyarakat (Ujung Pandang: Hasanuddin University Press, 1999), h. 17.

${ }^{11}$ Priyatna Abdurrasyid, Arbitrase \& Alternative Penyelesaian Sengketa: Suatu Pengantar (Jakarta: Fikahati Aneka, 2002), h. 155. 
Pihak ketiga dalam kapasitasnya sebagai mediator akan berusaha untuk mendamaikan para pihak yang bersengketa dengan memberikan saran penyelesaian sengketa. Jika saran tersebut tidak dapat diterima oleh para pihak, maka mediator masih dapat melanjutkan fungsi mediasinya dengan membuat usulan-usulan baru. Karena itu salah satu fungsi utama mediator adalah mencari berbagai solusi, mengidentifikasikan hal-hal yang dapat disepakati oleh para pihak, dan membuat usulanusulan baru yang dapat mengakhiri sengketa.

3. Penyelesaian sengketa melalui arbitrase

Apabila upaya para pihak dalam menyelesaikan sengketanya melalui negosiasi dan mediasi tidak tercapai, maka para pihak berdasarkan kesepakatan secara tertulis dapat mengajukan usaha penyelesaian sengketa melalui badan arbitrase. Penyelesaian sengketa melalui arbitrase merupakan penyelesaian sengketa di luar pengadilan yang bersifat mengikat dan final.

Arbitrase berasal dari kata arbitrare yang berarti kekuasaan untuk menyelesaiakan sesuatu menurut kebijaksanaan. Jadi arbitrase itu sebenarnya adalah lembaga peradilan oleh hakim partikelir/swasta (particuliere rechtspraak). ${ }^{12}$

Pasal 1 UU Nomor 30 tahun 1999 tentang Arbitrase dan Alternatif Penyelesaian Sengketa menyebutkan bahwa arbitrase adalah cara penyelesaian suatu sengketa perdata di luar peradilan umum yang didasarkan pada perjanjian arbitrase yang dibuat secara tertulis oleh para pihak yang bersengketa. ${ }^{13}$

Berdasarkan pengertian di atas, ada tiga hal yang mendasari dalam penyelesaian sengketa melalui arbitrase. Pertama, arbitrase merupakan salah satu bentuk penyelesaian secara non litigasi. Kedua, perjanjian arbitrase harus dibuat dalam bentuk tertulis. Ketiga, perjanjian arbitrase merupakan perjanjian untuk menyelesaikan sengketa yang dilaksanakan di luar peradilan umum.

Penyelesaian sengketa melalui arbitrase tidak diperuntukkan untuk menyelesaikan sengketa di luar sengketa

\footnotetext{
${ }^{12}$ Hasanuddin Rahman, Seri Keterampilan Merancang Kontrak Bisnis:
} Contract Draftig (Cet. I; Bandung: PT. Citra Aditya Bakti, 2003), h. 340.

${ }^{13}$ Republik Indonesia, "UU”, op. cit., h. 162. 
perdata. Dalam hal ini Achmad Ali mengemukakan bahwa penggunaan arbitrase hanya terbatas pada penyelesaian sengketa perdata. Arbitrase sering lebih cepat, lebih non formal, lebih murah, lebih mudah penyelesaiannya dan lebih rahasia ketimbang berperkara ke pengadilan. ${ }^{14}$

Dalam penjelasan umum UU Nomor 30 Tahun 1999 tentang Arbitrase dan Alternatif Penyelesaian Sengketa disebutkan bahwa pada umumnya lembaga arbitrase mempunyai kelebihan dibandingkan dengan lembaga peradilan. Kelebihan tersebut antara lain adalah:

1. Dijamin kerahasiaan sengketa para pihak.

2. Dapat dihindari kelambatan yang diakibatkan karena hal prosedur dan administrasi.

3. Para pihak dapat memilih arbiter yang menurut keyakinannya mempunyai pengetahuan, pengalaman serta latar belakang yang cukup mengenai masalah yang disengketakan, jujur dan adil.

4. Para pihak dapat memilih hukum apa yang akan diterapkan untuk menyelesaikan masalahnya serta proses dan tempat penyelenggaraan arbitrase.

5. Putusan arbiter merupakan putusan yang mengikat para pihak dan dengan melalui tata cara (prosedur) sederhana saja ataupun langsung dapat dilaksanakan. ${ }^{15}$

Dengan mengacu pada konvensi-konvensi seperti Convention of the Settlement of Investment Disputes Between States and Nation of Other State atau Convention on the Recognition and Enforcement of Foreign Arbitral Awards maupun berdasarkan ketentuan yang terdapat dalam UNCITRAL Arbitration and Rules, maka dapat dikemukakan beberapa jenis arbitrase, yaitu:

1. Arbitrase ad hoc

2. Arbitrase institusional

Jenis arbitrase ini merupakan jenis arbitrase yang diakui eksistensi dan kewenangannya untuk memeriksa dan memutus perselisihan yang terjadi antara para pihak yang bersengketa.

\footnotetext{
${ }^{14}$ Achmad Ali, op. cit., h. 27.

${ }^{15}$ Republik Indonesia, “UU”, op. cit., h. 194.
} 
Arbitrase ad hoc adalah arbitrase yang dibentuk khusus untuk menyelesaikan dan memutuskan sengketa tertentu. Arbitrase ini bersifat insidental dan jangka waktunya tertentu sampai sengketa itu diputus. Sedangkan arbitrase institusional merupakan lembaga atau badan arbitrase yang bersifat permanen. Arbitrase ini sering juga disebut dengan permanent arbitral body. Arbitrase ini disediakan oleh organisasi tertentu dan sengaja didirikan untuk menampung sengketa yang timbul dari kontrak atau perjanjian. Faktor kesengajaan dan sifat permanen ini merupakan ciri pembeda dengan arbitrase ad hoc. Selain itu arbitrase institusional ini sudah ada sebelum sengketa timbul yang berbeda dengan arbitrase ad hoc yang baru dibentuk setelah sengketa timbul. Selain itu, arbitrase institusional ini berdiri untuk selamnya dan tidak bubar meskipun sengketa yang ditangani telah selesai.

Apabila para pihak setuju untuk menyelesaikan sengketanya melalui arbitrase, maka para pihak menunjuk seseorang yang dapat bertindak sebagai arbiter. Arbiter tersebut harus betul-betul independen dan tidak memiliki hubungan kekeluargaan dengan para pihak yang bersengketa.

4. Penyelesaian sengketa melalui konsiliasi

Seperti halnya dengan mediasi, konsiliasi merupakan suatu proses penyelesaian sengketa di luar pengadilan antara para pihak yang bersengketa dengan melibatkan pihak ketiga yang netral dan tidak memihak.

Paa dasarnya, mediator dan konsiliator bertugas sebagai fasilitator untuk melakukan komunikasi antara para pihak yang bersengketa sehingga dapat ditemukan solusi yang dapat memuaskan para pihak itu sendiri. Hanya saja seorang konsiliator berperan sebatas untuk melakukan tindakan-tindakan seperti mengatur waktu dan tempat pertemuan para pihak yang bersengketa, mengarahkan topik pembicaraan, membawa pesan dari satu pihak kepada pihak lain jika pesan tersebut tidak mungkin disampaikan langsung atau para pihak tidak mau bertemu langsung. Sedangkan mediator, disamping dapat melakukan hal-hal yang dilakukan konsiliator, juga menyarankan solusi atau proposal penyelesaian sengketa, hal mana secara teoritis tidak ada dalam kewenangan pihak konsiliator. Dalam hal menggunakan konsiliasi atau mediasi, 
keputusan akhir dari suatu sengketa tetap terletak pada persetujuan para pihak yang bersengketa.

5. Penyelesaian sengketa oleh kepala desa

Sama halnya dengan penyelesaian sengketa melalui negosiasi, mediasi, arbitrase dan konsiliasi, penyelesaian sengketa oleh kepala desa juga merupakan bentuk penyelesaian sengketa di luar pengadilan yang lebih didominasi oleh hukum adat setempat. Cara penyelesaian sengketa oleh kepala desa sangat aktual dipraktekkan oleh masyarakat di desa dalam kehidupan sehari-hari. Biasanya jika terjadi suatu sengketa, maka pihak-pihak yang merasa dirugikan lebih dahulu mengadukan kepada kepala desanya untuk diselesaikan secara damai.

Peran kepala desa dalam menyelesaikan sengketa memiliki arti yang sangat penting, terutama dalam menciptakan suatu ketentraman dan ketertiban dalam masyarakat di dessa. Apabila terjadi suatu sengketa dalam masyarakat, maka kepala desa sebagai pemimpin pemerintahan desa bertugas dan berkewajiban untuk mendamaikan persengketaan tersebut, sebagaimana tercantum dalam Pasal 15 ayat (1) huruf k PP Nomor 72 Tahun 2005 tentang Desa disebutkan bahwa "Dalam melaksanakan tugas dan wewenang sebagaimana dimaksud dalam Pasal 14, kepala desa mempunyai kewajiban mendamaikan perselisihan masyarakat di desa". ${ }^{16}$

Penyelesaian sengketa di luar pengadilan (non litigasi) termasuk yang yang dipraktekkan oleh para kepala desa secara hukum dibenarkan dalam peraturan perundang-undangan. Dalam Penjelasan Pasal 3 ayat (1) UU Nomor 4 Tahun 2004 tentang Kekuasaan Kehakiman disebutkan bahwa "ketentuan ini tidak menutup kemungkinan penyelesaian perkara dilakukan di luar pengadilan negara melalui perdamaian atau arbitrase". ${ }^{17}$

Kepala des dalam menangani suatu sengketa akan bertindak sebagai mediator. Maksudnya, kepala desa dalam posisi sebagai pihak ketiga yang netral akan mempertemukan dan berusaha mendamaikan para pihak yang bersengketa.

${ }^{16}$ Republik Indonesia, "PP Nomor 72 Tahun 2005 tentang "Desa" dalam Himpunan Peraturan Perundang-undangan tentang Pemerintahan Desa dan Kelurahan (Cet. I; Bandung: Fokusmedia, 2006), h. 11.

${ }^{17}$ Republik Indonesia, "UU”, op. cit., h. 20. 
Kepala desa dalam mendamaikan para pihak yang bersengketa dapat dibantu oleh lembaga adat desa. Dalam suatu komunitas setingkat desa, pada umumnya masyarakat taat pada aturan adat atau kebiasaan yang hidup dan tumbuh dalam masyarakat.

Iman Sudiyati mengemukakan bahwa hukum adat tumbuh, dianut, dan dipertahankan sebagai peraturan penjaga tata tertib sosial dan tata tertib hukum diantara manusia yang bergaul dalam masyarakat, supaya dengan demikian dapat dihindarkan segala bencana dan bahaya yang mungkin atau telah mengancam. ${ }^{1}$

Dalam PP Nomor 72 Tahun 2005 tentang Desa dijelaskan bahwa apabila di desa tidak terdapat suatu lembaga adat, maka kepala desa diperbolehkan meminta kepada tokohtokoh agama maupun tokoh-tokoh masyarakat lainnya untuk membantu kepala desa dalam mendamaikan para pihak yang bersengketa. Oleh karena itu, dengan menggunakan pendekatan adat, agama dan tokoh-tokoh masyarakat, biasanya kepala desa lebih mudah mendamaikan para pihak yang bersengketa.

Dengan konsep pemikiran sebagaimana diungkap di atas, maka dapat dipahami bahwa seorang kepala desa sebagai kepala persekutuan hukum adalah kepala rakyat, bapak masyarakat, yang secara moral wajib menjaga ketentraman dalam kelompoknya, membuat dan menjaga hukum kelompoknya, mendamaikan setiap perselisihan sehingga tercipta kedamaian dan keserasian dalam bertingkah laku dan bermasyarakat. $^{19}$

\section{PENUTUP}

Berdasarkan uraian yang dikemukakan di atas, dapat disimpulkan bahwa umumnya terdapat beberapa cara yang dapat dipilih untuk menyelesaikan suatu sengketa yang terjadi. Caracara yang dimaksud adalah:

1. Penyelesaian sengketa secara litigasi, yakni suatu bentuk penyelesaian sengketa yang dilakukan di pengadilan dengan mengikuti tata cara persidangan menurut ketentuan hukum acara. Para pihak yang bersengketa berhadap-hadapan untuk

\footnotetext{
${ }^{18}$ Iman Sudiyati, Asas-asas Hukum Adat (Yogyakarta: Liberty, 1999), h. 33 .

${ }^{19}$ Ibid.
} 
saling mengalahkan, diadakan di pengadilan, dan hasilnya berupa putusan.

2. Penyelesaian sengketa secara non litigasi, yakni suatu bentuk penyelesaian sengketa yang dilakukan di luar pengadilan. Penyelesaian sengketa secara non litigasi dapat berupa negosiasi antara para pihak yang bersengketa untuk mencapai kata mufakat, mediasi, arbitrase, dan konsiliasi yang masing-masing menunjuk pihak ketiga yang bersifat netral untuk membantu penyelesaian sengketa yang terjadi. Selain itu terdapat pula bentuk penyelesaian sengketa secara adat, yakni penyelesaian sengketa oleh kepala desa yang memang sangat aktual dalam kehidupan sehari-hari khususnya dalam masyarakat desa. Pelaksanaan penyelesaian non litigasi ini sifatnya lebih mudah diatur sendiri oleh para pihak yang bersengketa tanpa terikat pada ketentuan hukum acara yang sifatnya kaku. 


\section{DAFTAR PUSTAKA}

Abdurrasyid, Priyatna. Arbitrase \& Alternative Penyelesaian Sengketa: Suatu Pengantar. Jakarta: Fikahati Aneka, 2002.

Ali, Achmadi.Menguak Tabir Hukum (Suatu Kajian Filosofis dan Sosiologis). Cet. I; Jakarta: Chandra Pratama, 1996.

-Pengadilan dan Masyarakat. Ujung Pandang: Hasanuddin University Press, 1999.

Bagus, Ida Wyasa Putra. Aspek-aspek Hukum Perdata Internasional dalam Transaksi Bisnis Internasional Cet. I; Bandung: Refika Aditama, 2000

Fuady, Munir.Arbitrase Nasional (Alternatif Penyelesaian Sengketa Bisnis). Bandung: PT citra Aditya Bakti, 2004.

Mertokusumo, Sudikno. Hukum Acara Perdata Indonesia. Cet. I; Yogyakarta: Liberty, 1993.

Rahman, Hasanuddin Seri Keterampilan Merancang Kontrak Bisnis: Contract Draftig. Cet. I; Bandung: PT. Citra Aditya Bakti, 2003.

Republik Indonesia, "PP Nomor 72 Tahun 2005 tentang "Desa" dalam Himpunan Peraturan Perundang-undangan tentang Pemerintahan Desa dan Kelurahan. Cet. I; Bandung: Fokusmedia, 2006.

Republik Indonesia, "UU Noor 30 Tahun 1999 tentang Arbitrase dan Alternatif Penyelesaian Sengketa" dalam Gatot Soemartono, Arbitrase dan Mediasi di Indonesia. Cet. I; Jakarta: PT Gramedia Pustaka Utama, 2006.

Soemartono, Gatot. Arbitrase dan Mediasi di Indonesia. Cet. I; Jakarta: PT Gramedia Pustaka Utama, 2006

Sudiyati, Iman Asas-asas Hukum Adat. Yogyakarta: Liberty, 1999

Wijaya, Gunawan dan Achmad Yani. hukum Arbitrase. Jakarta: PT Raja Grafindo Persada, 2000. 